\title{
Resenha: Freud e Lévi-Strauss: Influências, Contribuições e Insuficiências das Antropologias Dinâmica e Estrutural ${ }^{1}$
}

\author{
Henrique Fróes ${ }^{2}$ \\ Terezinha de Camargo Viana \\ Universidade de Brasília
}

\section{Book Review: Freud and Lévi-Strauss: Influences, Contributions and Inadequacies of Dynamic and Structural Anthropologies}

Poucos pensadores das ciências sociais mantiveram um diálogo tão profundo e constante com a psicanálise como Lévi-Strauss. Desde a sua primeira grande obra - As estruturas elementares do parentesco - o antropólogo belga elegeu Freud como um de seus interlocutores privilegiados na criação e desenvolvimento da sua antropologia estrutural. Alguns autores chegam a afirmar que o pai da psicanálise foi o autor que teve o maior impacto sobre a obra de Lévi-Strauss (Badcock, 1975).

A relação entre a obra de dois dos maiores pensadores do século XX é abordada no livro de Espina Barrio (2008), intitulado Freud e Lévi-Strauss: influências, contribuições e insuficiências das antropologias dinâmica e estrutural (Editora Massangana, 224 páginas, tradução de Luiz Nilton Corrêa). O livro é uma adaptação da tese de doutorado do autor, que é professor titular de antropologia social na Universidade de Salamanca e mantém laços constantes com o Brasil, ministrando cursos e participando de eventos acadêmicos.

No livro, Espina Barrio adota o procedimento de, primeiro, expor como um conceito ou tema aparece na teoria freudiana; em seguida, faz o mesmo em relação ao pensamento de Lévi-Strauss para, num terceiro momento, estabelecer as concordâncias e diferenças entre os dois. Desse modo são abordados temas como o parentesco e o Complexo de Édipo, o totemismo, o mito e o inconsciente, além das concepções antropológicas de cada autor. Autores diversos como Green, Lacan, Jung, Marcuse e Ricoeur, entre muitos outros, são utilizados nesse debate, enriquecendo e problematizando os tópicos abordados.

Espina Barrio promove a retomada de um diálogo entre dois campos do saber - psicanálise e antropologia - muito pouco cultivado hoje em dia. Para os estudiosos da primeira, tal diálogo ajuda a iluminar aspectos fundamentais do pensamento freudiano, principalmente as obras que versam sobre a cultura e o social, especialmente Totem e Tabu. O controverso texto de 1913 ganha no livro contextualização histórica (a influência do evolucionismo cultural) e a necessária crítica em relação a seus pressupostos antropológicos (como a ideia superada de que o totemismo fosse uma fase universal do desenvolvimento dos povos). Em diferentes momentos de sua trajetória, Lévi-Strauss também se ocupa desse texto freudiano, sem poupá-lo, principalmente em $\mathrm{O}$ totemismo

1 Apoio: CNPq.

2 Endereço para correspondência: UnB/PCL, Campus Universitário Darcy Ribeiro, Departamento de Psicologia Clínica, ICC Ala Sul, Brasília, DF, CEP: 70910-900. E-mail: henrique.froes@gmail.com hoje, de severas restrições. Nele, o antropólogo belga critica a tentativa de explicar a persistência de costumes sociais por meio de emoções ou pulsões vividas singularmente pelos indivíduos, o que, na sua opinião, "arruína a tentativa de Freud" (Lévi-Strauss, 2003, p. 92). Após ser devidamente depurado por Espina Barrio, Totem e Tabu sobrevive no seu status de mito psicanalítico.

Outra obra fundamental de Freud, O Mal-estar na civilização, ganha uma nova leitura, oposta à que considera pessimista a visão freudiana da condição humana. Baseado em ideias de Marcuse e da relativização inerente à prática e ao pensamento antropológico, Espina Barrio (2008) defende que não há uma incompatibilidade entre cultura e sexualidade e que, por meio de um trabalho erotizado, é possível canalizar os impulsos agressivos para fins sociais.

Esta é a brecha de esperança que Freud abriu timidamente nas últimas linhas do que em realidade foi seu descontentamento com a civilização: evitar o desperdício de energias na vida sexual dos homens e exigi-las dos instintos agressivos, em virtude de um progresso e uma cultura mais humanizados. (p. 157).

Já o pensamento de Lévi-Strauss se notabilizou pela rejeição da noção de sujeito em nome do combate ao etnocentrismo e de uma maior exatidão nas ciências sociais, fornecendo as bases para a "morte do sujeito" preconizada por Focault, Deleuze, Guattari, etc.

As diferenças entre Freud e Lévi-Strauss ficam mais evidentes no conceito de inconsciente que cada um utiliza em suas obras. Espina Barrio contrapõem as características estabelecidas por cada autor: pulsional/formal, afetivo-representativo/gramatical, cheio/vazio, individual/universal, psicológico/sociológico. Nesse ponto, o livro interessa particularmente aos lacanianos, pois a noção de inconsciente de Lévi-Strauss é fundamental para a releitura de Freud proposta por Lacan (Dosse, 1993). No entanto, Espina Barrio (2008) defende uma nova leitura estruturalista do pensamento freudiano:

(...) pode ocorrer uma assimilação da antropologia estrutural pela psicanálise, diferente da representada por Lacan. Pode-se dizer, uma teoria da hermenêtica que tome os pontos fortes, e não os débeis, de ambos os enfoques e que sirva para sair da redução a que estavam condenados em separado. (p. 168).

Em alguns momentos, o autor extrapola sua intenção original. É o caso da análise de cunho psicanalítico que ele 
traz no capítulo O Mito e o inconsciente a partir de uma compilação de canções militares espanholas. O trecho destoa do restante da obra e parece não acrescentar muito como exemplo de uma análise mitológica simbólica. Em outros, como no capítulo Totem e tabu ou A Ilusão arcaica, Espina Barrio não elabora as conclusões que retira do confronto entre os dois pensamentos, deixando incompleta a sua proposta original.

Freud e Lévi-Strauss está longe de esgotar as possíveis relações entre os dois autores. Ficam de fora do texto as desconfianças que o antropólogo belga possui em relação à eficácia terapêutica do método analítico, bem como sua visão de que a obra freudiana não passaria de uma mitologia ocidental singular (Dosse, 1993). Também são pouco explorados dois textos fundamentais de Lévi-Strauss - O feiticeiro e sua magia e A eficácia simbólica - que, segundo Dosse (1993), vão ter grande influência no pensamento psicanalítico. Por outro lado, o livro traz em anexo uma extensa lista de obras e artigos que discutem os pensamentos de Freud e Lévi-Strauss que serve como uma excelente referência para quem pretende se aprofundar na relação entre dois gigantes do pensamento ocidental do século XX.

\section{Referências}

Badcock, C. R. (1975). Lévi-Strauss: Estruturalismo e Teoria Sociológica. Rio de Janeiro, RJ: Zahar Editores.

Dosse, F. (1993). História do Estruturalismo, v. 1: O campo do signo, 1945-1966. São Paulo: Ensaio; Campinas, SP: Editora da Universidade Estadual de Campinas.

Espina Barrio, Á. B. (2008). Freud e Lévi-Strauss: Influências, contribuições e insuficiências da antropologia dinâmica e estrutural. Recife: Editora Massangana.

Lévi-Strauss, C. (2003). O Totemismo hoje. Lisboa: Edições 70.

Recebido em 17.02.2011

Primeira decisão editorial em 18.06.2013

Versão final em 25.06.2013

Aceito em 22.07.2013 